\title{
Coupled Kinetics Model for Microbially Mediated Arsenic Reduction and Adsorption/Desorption on Iron Oxides: Role of Arsenic Desorption Induced by Microbes
}

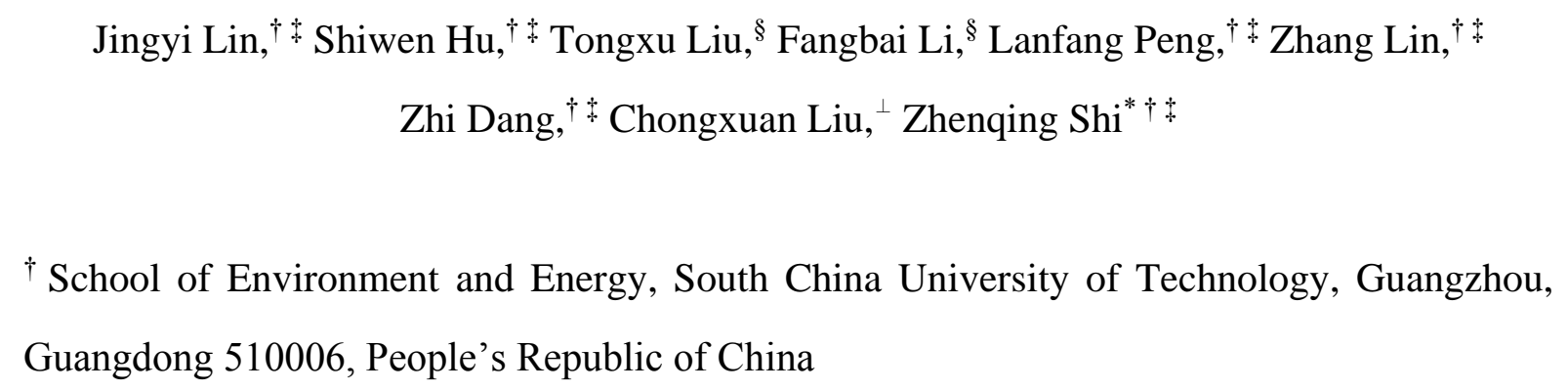

${ }^{\dagger}$ School of Environment and Energy, South China University of Technology, Guangzhou, Guangdong 510006, People's Republic of China

$\$$ The Key Lab of Pollution Control and Ecosystem Restoration in Industry Clusters, Ministry of Education, South China University of Technology, Guangzhou, Guangdong 510006, People's Republic of China

$\S$ Guangdong Key Laboratory of Agricultural Environment Pollution Integrated Control, Guangdong Institute of Eco-Environmental Science and Technology, Guangzhou 510650, People's Republic of China

$\perp$ State Environmental Protection Key Laboratory of Integrated Surface Water-Groundwater Pollution Control, School of Environmental Science and Engineering, Southern University of Science and Technology, Shenzhen, 518055, People's Republic of China

*Corresponding author: phone: 86-20-39380503, fax: 86-20-39380508, email: zqshi@scut.edu.cn,

Total 19 pages, 11 figures and 5 tables. 
S1. Additional details of the literature data.

\section{Assessment of iron mineral dissolution in the literature data}

Previous literature data were collected for analysis. In this study, we mainly focused on experimental data which showed minimal iron mineral transformation during the kinetic experiments and the reductive dissolution of iron oxides was insignificant for As release. After carefully review of the kinetic data from literatures, total 11 studies were selected for model analysis as described in the main text. Some studies, from Huang and coauthors, ${ }^{1-4}$ employed relatively low lactate concentrations, in which the reductive dissolution of $\mathrm{Fe}(\mathrm{III})$ was minimal. In the rest of the studies, the formation of secondary iron minerals was either monitored or assessed based on the Fe(II) concentrations during the kinetic experiments. There is one related study by Langner et al. (2000), ${ }^{5}$ which was not analyzed due to the high initial Fe(II) present in the solution.

The degrees of $\mathrm{Fe}(\mathrm{III})$ reduction in all of the 11 studies were mainly assessed based on the $\mathrm{Fe}(\mathrm{II})$ data in the original studies if available. When only solution $\mathrm{Fe}(\mathrm{II})$ concentrations were present, we used the surface complexation model (SCM) in Visual MINTEQ 3.1 to calculate adsorbed $\mathrm{Fe}$ (II) based on the solution Fe(II) concentrations and then summed them as the total $\mathrm{Fe}(\mathrm{II})$ produced. The SCM for $\mathrm{HFO}^{6}$ was used with the same solution parameters, SSA, and iron oxides concentrations for $\mathrm{As}(\mathrm{V}) \& \mathrm{As}(\mathrm{III})$ calculations mentioned in the main text. For experiments running for long time, we only analyzed data during the first a few days, in which iron mineral dissolution and transformation was minimal. The results are summarized in Table S1. D1 used deactivated $\mathrm{CN}-32$ bacterial cells, so no Fe(III) reduction occurred during the experiments. In both D2 and D3, original studies indicated negligible Fe(II) produced in the experiments. D4 did not have Fe(II) extraction data so the total reduced Fe(III) was not estimated. D4 had similar experimental conditions as used in D2 and D3. Data sets D5, D6 and D11 had very minimal Fe(III) reduction and Fe(II) production (less than $0.5 \%$ ). Some studies had higher $\mathrm{Fe}(\mathrm{III})$ reduction and $\mathrm{Fe}(\mathrm{II})$ production ranging from $3 \%-8 \%$, including data set D7, D8, D9, and D10.

Although most previous studies suggested the long-term As mobility as a consequence of microbial reductive dissolution of Fe(III) minerals, the contribution of biogenic Fe(III) reduction to $\mathrm{As}(\mathrm{V})$ release and sequestration was small in those analyzed 11 studies. To 
54 simplify the model, the small amount of As released by Fe(III) mineral reductive dissolution 55 was not considered in our kinetic model. Based on the total Fe(II) results, in data sets D7, D8, 56 D9, D10, and D11, we only analyzed shorter time than the original studies, in which Fe(II) 57 analysis indicated minimal Fe oxide reduction and dissolution. The reaction time periods we analyzed are also listed in Table S1 for all 11 studies.

Table S1. Summary of the Fe(III) reduction in the literature data

\begin{tabular}{cccc}
\hline Reference & Reaction time $(\mathrm{h})$ & $\%$ Fe(III) reduced & method \\
\hline D1 & 100 & \multicolumn{2}{c}{ No reduction } \\
D2 & 100 & Negligible & Total Fe(II) extraction \\
D3 & 100 & Negligible & \multicolumn{2}{c}{ Refer to D2 } \\
D4 & 100 & Negligible $(<0.5 \%)$ & Total Fe(II) extraction \\
D5 & 144 & Negligible & SCM Calculation \\
D6 & 40 & $7.6 \%$ & SCM Calculation \\
D7 & 100 & $7 \%$ & SCM Calculation \\
D8 & 20 & $3.6 \% \sim 7 \%$ & Total Fe(II) extraction \\
D9 & 70 & $8.3 \%$ & SCM Calculation \\
D10 & 200 & Negligible & Total Fe(II) extraction \\
D11 & 350 & &
\end{tabular}

60

\section{Additional details of the kinetic experiments}


Table S2. Additional details of the kinetic experiments

\begin{tabular}{|c|c|c|c|c|}
\hline Reference & $\begin{array}{c}\text { Background electrolyte or } \\
\text { ionic strength }\end{array}$ & Buffer solution & $\begin{array}{c}\text { Shaking } \\
\text { speed (rpm) }\end{array}$ & Temperature \\
\hline D1 & $\begin{array}{c}5 \mathrm{mM} \mathrm{NaCl}, 0.5 \mathrm{mM} \mathrm{CaCl}_{2}, \\
0.5 \mathrm{mM} \mathrm{MgCl}_{2} \\
\end{array}$ & 10 mM PIPES & NA & $\begin{array}{c}\text { room } \\
\text { temperature }\end{array}$ \\
\hline $\begin{array}{l}\text { D2 } \\
\text { D3 } \\
\text { D4 }\end{array}$ & $\begin{array}{c}5 \mathrm{mM} \mathrm{NaCl}, 0.5 \mathrm{mM} \mathrm{CaCl}_{2}, \\
0.5 \mathrm{mM} \mathrm{MgCl} 2\end{array}$ & 10 mM PIPES & 250 & $25^{\circ} \mathrm{C}$ \\
\hline D5 & $\begin{array}{c}5 \mathrm{mM} \mathrm{NaH} \mathrm{PO}_{4}, 20 \mathrm{mM} \mathrm{KCl}, \\
28 \mathrm{mM} \mathrm{NH}_{4} \mathrm{Cl}\end{array}$ & 10 mM HEPES & NA & $30^{\circ} \mathrm{C}$ \\
\hline D6 & $\begin{array}{l}0.17 \mathrm{M} \mathrm{NaCl}, \\
0.05 \mathrm{M} \mathrm{CaCl}_{2}\end{array}$ & NA & 150 & $30^{\circ} \mathrm{C}$ \\
\hline D7 & $\begin{array}{c}170 \mathrm{mM} \mathrm{NaCl}, 3 \mathrm{mM} \mathrm{KCl}, \\
30 \mathrm{mM} \mathrm{NaHCO}_{3}, \\
18 \mathrm{mM} \mathrm{NH}_{4} \mathrm{CL}, 0.5 \mathrm{mM} \mathrm{CaCl}_{2}\end{array}$ & 30 mM HEPES & NA & $30^{\circ} \mathrm{C}$ \\
\hline D8 & $\begin{array}{c}5 \mathrm{mM} \mathrm{NaCl}, 0.5 \mathrm{mM} \mathrm{CaCl}_{2}, \\
0.5 \mathrm{mM} \mathrm{MgCl}_{2} \\
\end{array}$ & $7.5 \mathrm{mM}$ HEPES & 250 & $25^{\circ} \mathrm{C}$ \\
\hline D9 & ionic strength $=0.06 \mathrm{M}$ & $\begin{array}{c}50 \mathrm{mM} \\
\text { bicarbonate } \\
\text { buffer }\end{array}$ & NA & $30^{\circ} \mathrm{C}$ \\
\hline D10 & $\begin{array}{c}0.15 \mathrm{mM} \mathrm{NaCl} \\
45 \mu \mathrm{M} \mathrm{Na}_{2} \mathrm{HPO}_{4} \\
20 \mathrm{mM} \mathrm{Na} \text { lactate }\end{array}$ & 4.5 mM PIPES & 160 & $\begin{array}{c}\text { room } \\
\text { temperature }\end{array}$ \\
\hline D11 & $\begin{array}{c}17 \mathrm{mM} \mathrm{NaCl}^{2} 2 \mathrm{mM} \mathrm{CaCl}_{2} \\
6.5 \mathrm{mM} \mathrm{CaCl}_{2}, 7 \mathrm{mM} \mathrm{KCl}, 4.5 \\
\mathrm{mM} \mathrm{NH}_{4} \mathrm{CL} \\
\end{array}$ & NA & NA & $30^{\circ} \mathrm{C}$ \\
\hline
\end{tabular}

NA: not available

66

S2. Description of model calculations and parameters

\section{Derivations of equations 6 and 7 in the main text}

Since iron oxides had multiple heterogeneous binding sites, there were multiple adsorption and desorption rate coefficients to be determined for all those sites in the kinetics model. In our previous modeling studies, ${ }^{7,8}$ we have developed theoretic relationships to constrain the adsorption/desorption rate coefficients among those heterogeneous binding sites. $\mathrm{As}(\mathrm{V})$ desorption rates, which can be described as,

$$
k_{\mathrm{d} i, \operatorname{As}(\mathrm{V})} \mathrm{C}_{\mathrm{p} i, \mathrm{As}(\mathrm{V})}=k_{\mathrm{a} i, \operatorname{As}(\mathrm{V})} \mathrm{C}_{\mathrm{ion}, \mathrm{As}(\mathrm{V})}
$$


and we have,

$$
k_{\mathrm{a} i}=k_{\mathrm{d} i} \mathrm{C}_{\mathrm{p} i, \mathrm{As}(\mathrm{V})} / \mathrm{C}_{\mathrm{ion}, \mathrm{As}(\mathrm{V})}=k_{\mathrm{d} i} K_{\mathrm{p} i}
$$

Note that in equation $\mathrm{S} 2$, the partition coefficient $K_{\mathrm{p} i}$ is a function of reaction chemistry conditions and the adsorbed $\mathrm{As}(\mathrm{V})$ concentration on the specific binding site $\left(\mathrm{C}_{\mathrm{p} i}\right)$. It suggests that the local equilibrium determined by $\mathrm{C}_{\mathrm{p} i}$ is the driving force of the kinetic reaction and does not require the reaction to be at equilibrium. Detailed discussion can be found in our previous papers. ${ }^{7-9}$

Secondly, there was intrinsic relationship for the desorption rate coefficients among different binding sites, derived as follows,

$$
\log K_{\mathrm{M} i}=\log k_{\mathrm{a} i}-\log k_{\mathrm{d} i}
$$

and

$$
\log K_{\mathrm{M} j}=\log k_{\mathrm{aj}}-\log k_{\mathrm{d} j}
$$

Then we have

$$
\left(\log K_{\mathrm{M} i}-\log K_{\mathrm{M} j}\right)=\left(\log k_{\mathrm{dj} j}-\log k_{\mathrm{d} i}\right)+\left(\log k_{\mathrm{a} i}-\log k_{\mathrm{aj}}\right)
$$

It is not clear how the variations of $K_{\mathrm{M} i}$ affect the $k_{\mathrm{a} i}$ or $k_{\mathrm{d}}$, and we assume that the changes of $K_{\mathrm{M} i}$ had equal impact on the changes of $k_{\mathrm{a} i}$ and $k_{\mathrm{d} i}$. Then we have,

$$
\begin{aligned}
& 0.5\left(\log K_{\mathrm{M} i}-\log K_{\mathrm{M} j}\right)=\left(\log k_{\mathrm{dj}}-\log k_{\mathrm{d} i}\right) \\
& 0.5\left(\log K_{\mathrm{M} i}-\log K_{\mathrm{M} j}\right)=\left(\log k_{\mathrm{a} i}-\log k_{\mathrm{aj}}\right)
\end{aligned}
$$

Therefore, equations 6 and 7 in the main text significantly reduced kinetic model parameters to be determined through model fitting.

\section{Details of Visual MINTEQ calculations}

Table S3 summarized all surface complexation reactions used in the CD-MUSIC model in Visual MINTEQ. For the calculations of the CD-MUSIC model, the major input parameters include solution cation/anion concentrations, microbial competition component $\mathrm{RO}^{-}$, reaction $\mathrm{pH}$, and the iron oxide concentrations. The solution cation/anion concentrations were input as used in the experiments. The $\mathrm{pH}$ values reported in the experiments were used. If experiments indicated that $\mathrm{pH}$ varied during kinetic experiments, the final reaction $\mathrm{pH}$ was used if reported. For the iron oxide phases, ferrihydrite and goethite concentrations were input as used. The specific surface areas (SSA) of iron oxides for all studies were determined based on the initial 
equilibrium status of As(V) adsorption on iron oxides, in which the SSA of iron oxides in each experiment was manually adjusted to provide the best fit of the initial equilibrium concentrations of $\mathrm{As}(\mathrm{V})$. For those experiments with very low initial $\mathrm{As}(\mathrm{V})$ concentrations, SSA was further adjusted during model fitting processes, which provided the best model fits for the kinetic data. Most studies involved two reaction systems, As-ferrihydrite-bacteria and As-goethite-bacteria, while the starting experimental conditions and reaction time varied. Only in one study, ${ }^{10}$ both ferrihydrite and goethite co-existed during the kinetic experiments, and our chemical speciation calculations indicated that ferrihydrite played a dominant role in controlling As(III)\&As(V) speciation. To simplify the model, we divided the concentrations of goethite by a factor of 6 and input it as ferrihydrite in Visual MINTEQ calculations, an approach we used previously. ${ }^{11}$

Table S3. Surface complexation reactions used in Visual MINTEQ calculations Surface complexation reactions for $\mathrm{As}(\mathrm{V}) / \mathrm{As}(\mathrm{III}) / \mathrm{RO}^{-}$reactions with ferrihydrite ${ }^{\mathrm{a}}$

\begin{tabular}{ll}
\hline Reaction & $\operatorname{logK}$ \\
\hline (1) $\mathrm{AsO}_{4}{ }^{3-}+\mathrm{SOH}^{1 / 2-}+3 \mathrm{H}^{+} \leftrightarrow \mathrm{SOAsO}_{3} \mathrm{H}_{2}{ }^{1 / 2-}+2 \mathrm{H}_{2} \mathrm{O}$ & 28.9 (bidentate protonated) \\
(2) $\mathrm{AsO}_{4}{ }^{3-}+2 \mathrm{SOH}^{1 / 2-}+2 \mathrm{H}^{+} \leftrightarrow \mathrm{S}_{2} \mathrm{O}_{2} \mathrm{AsO}_{2}{ }^{2-}+2 \mathrm{H}_{2} \mathrm{O}$ & 27.4 (bidentate non- \\
protonated) \\
(3) $\mathrm{AsO}_{4}{ }^{3-}+2 \mathrm{SOH}^{1 / 2-}+3 \mathrm{H}^{+} \leftrightarrow \mathrm{S}_{2} \mathrm{O}_{2} \mathrm{AsOOH}^{-}+2 \mathrm{H}_{2} \mathrm{O}$ & 32.04 (monodentate) \\
(4) $\mathrm{H}_{3} \mathrm{AsO}_{3}+2 \mathrm{SOH}^{1 / 2-} \leftrightarrow \mathrm{S}_{2} \mathrm{O}_{2} \mathrm{AsOH}^{-}+2 \mathrm{H}_{2} \mathrm{O}$ & 6.05 (bidentate) \\
(5) $\mathrm{RO}^{-}+\mathrm{SOH}^{1 / 2-}+\mathrm{H}^{+1} \leftrightarrow \mathrm{SOR}^{1 / 2-}+\mathrm{H}_{2} \mathrm{O}$ & 25 \\
\hline
\end{tabular}

Surface complexation reactions for $\mathrm{As}(\mathrm{V}) / \mathrm{As}(\mathrm{III}) / \mathrm{RO}^{-}$reactions with goethite ${ }^{\mathrm{b}}$

\begin{tabular}{ll}
\hline Reaction & $\operatorname{logK}$ \\
\hline (1) $\mathrm{AsO}_{4}{ }^{3-}+2 \mathrm{SOH}^{1 / 2-}+3 \mathrm{H}^{+} \leftrightarrow \mathrm{S}_{2} \mathrm{O}_{2} \mathrm{AsOOH}^{-}+2 \mathrm{H}_{2} \mathrm{O}$ & 34.7 (bidentate protonated) \\
(2) $\mathrm{AsO}_{4}{ }^{3-}+2 \mathrm{SOH}^{1 / 2-}+2 \mathrm{H}^{+} \leftrightarrow \mathrm{S}_{2} \mathrm{O}_{2} \mathrm{AsO}_{2}{ }^{2-}+2 \mathrm{H}_{2} \mathrm{O}$ & $\begin{array}{l}27.7 \text { (bidentate non- } \\
\text { protonated) }\end{array}$ \\
(3) $\mathrm{AsO}_{4}{ }^{3-}+\mathrm{SOH}^{1 / 2-}+\mathrm{H}^{+} \leftrightarrow \mathrm{SOAsO}_{3}{ }^{5 / 2-}+\mathrm{H}_{2} \mathrm{O}$ & 19 (monodentate) \\
(4) $\mathrm{H}_{3} \mathrm{AsO}_{3}+2 \mathrm{SOH}^{1 / 2-} \leftrightarrow \mathrm{S}_{2} \mathrm{O}_{2} \mathrm{AsOH}^{-}+2 \mathrm{H}_{2} \mathrm{O}$ & 7.2 (bidentate) \\
(5) $\mathrm{H}_{3} \mathrm{AsO}_{3}+\mathrm{SOH}^{1 / 2-} \leftrightarrow \mathrm{SOAs}(\mathrm{OH})_{2}{ }^{1 / 2-}+\mathrm{H}_{2} \mathrm{O}$ & 4.41 (monodentate) \\
(6) $\mathrm{RO}^{-}+\mathrm{SOH}^{1 / 2-}+\mathrm{H}^{+} \leftrightarrow \mathrm{SOR}^{1 / 2-}+\mathrm{H}_{2} \mathrm{O}$ & 25 \\
\hline
\end{tabular}

${ }^{\text {a }}$ Parameters for ferrihydrite complexation reactions are from Gustafsson and coauthors $(2007,2013,2016),{ }^{12-14}$ and for $\mathrm{RO}^{-}$are from Gustafsson (2006). ${ }^{15}$

${ }^{\mathrm{b}}$ Parameters for goethite complexation reactions are from Weng et al. (2001), ${ }^{16,17}$ and for $\mathrm{RO}^{-}$are from Gustafsson (2006). ${ }^{15}$ 

oxides may play important roles in inducing As desorption from iron oxides. It is difficult to independently determine the competition effect for various studies and we employed the approach used previously to account for the competition effect. ${ }^{15}$ A reactive component $\mathrm{RO}^{-}$ was introduced to compete with both $\mathrm{As}(\mathrm{V})$ and $\mathrm{As}(\mathrm{III})$ for binding to iron oxides, with the binding constant from the previous study. ${ }^{15}$ A manual trial-and-error method was employed to determine the suitable concentration of $\mathrm{RO}^{-}$in each study, which is presented in Table S4. The sensitivity of $\mathrm{RO}^{-}$concentration was tested and discussed in the modeling section.

Table S4. Additional model parameters related to bacterial reactions

\begin{tabular}{|c|c|c|c|c|c|c|c|}
\hline $\begin{array}{c}\text { Data } \\
\text { set }\end{array}$ & $\begin{array}{c}\text { Iron } \\
\text { oxide }\end{array}$ & $\begin{array}{c}\mathrm{SSA} \\
\left(\mathrm{m}^{2} \mathrm{~g}^{-1}\right)\end{array}$ & Bacteria & $\begin{array}{c}{\left[\mathrm{RO}^{-}\right]} \\
(\mu \mathrm{M}) \\
\end{array}$ & $k_{0}\left(\mathrm{~h}^{-1}\right)$ & $b\left(\mathrm{~h}^{-1}\right)$ & $\begin{array}{l}\begin{array}{l}\text { Reaction } \\
\text { time }(\mathrm{h})\end{array} \\
\end{array}$ \\
\hline \multirow{2}{*}{ D1 } & $\mathrm{Fh}$ & 300 & \multirow{2}{*}{ Killed CN-32 } & 400 & \multirow{2}{*}{ I } & \multirow{2}{*}{ I } & \multirow{2}{*}{100} \\
\hline & $\mathrm{Gt}$ & 15 & & 150 & & & \\
\hline \multirow{2}{*}{ D2 } & Fh & 300 & \multirow{2}{*}{$\mathrm{CN}-32$} & 400 & 0.20 & 0.099 & \multirow{2}{*}{100} \\
\hline & $\mathrm{Gt}$ & 15 & & 150 & 0.55 & 0.038 & \\
\hline D3 & Gt & 15 & $\mathrm{CN}-32$ & 120 & 0.033 & 0.02 & 100 \\
\hline \multirow{2}{*}{ D4 } & \multirow{2}{*}{$\mathrm{Fh}$} & \multirow{2}{*}{300} & \multirow{2}{*}{$\mathrm{CN}-32$} & \multirow{2}{*}{700} & 0.006 & 0.001 & 100 \\
\hline & & & & & 0.082 & 0.031 & 100 \\
\hline \multirow{2}{*}{ D5 } & \multirow{2}{*}{$\mathrm{Fh}$} & \multirow{2}{*}{110} & ANA-3 & \multirow{2}{*}{0} & 0.20 & 0.081 & \multirow{2}{*}{144} \\
\hline & & & FERM & & 0.49 & 0.18 & \\
\hline D6 & $\mathrm{Fh}$ & 650 & Pantoea sp. IMH & 0 & 0.24 & 0.07 & 40 \\
\hline D7 & $\mathrm{Fh}$ & 300 & S. putrefaciens 200 & 0 & 0.032 & 0.0004 & 100 \\
\hline D8 & Fh & 650 & S. barnesii SES-3 & 600 & 0.80 & 0 & 20 \\
\hline \multirow{4}{*}{ D9 } & \multirow{4}{*}{$\mathrm{Fh}$} & \multirow{4}{*}{150} & \multirow{4}{*}{ Sediment bacteria } & \multirow{4}{*}{0} & \multirow{3}{*}{0.02} & 0.025 & \multirow{4}{*}{70} \\
\hline & & & & & & 0.005 & \\
\hline & & & & & & 0.01 & \\
\hline & & & & & 0.20 & 0.009 & \\
\hline \multirow{2}{*}{ D10 } & \multirow{2}{*}{ Fh } & \multirow{2}{*}{150} & ANA-3 & \multirow{2}{*}{1500} & 0.14 & 0.0005 & \multirow{2}{*}{200} \\
\hline & & & $\mathrm{CN}-32$ & & 0.098 & 0.001 & \\
\hline D11 & Fh & 300 & Soil bacteria & 4000 & 0.90 & 0.0005 & 350 \\
\hline
\end{tabular}

\section{Model fitting procedures}

The default As(III)\&As(V) binding parameters in CD-MUSIC were used in model calculations without any adjustment, and the $\mathrm{RO}^{-}$concentrations, reduction rate coefficients, and desorption rate coefficients varied among different experiments. To obtain the kinetic

137 model parameters, each data set was fitted using Excel SOLVER program as explained in the 
main text. For each data set, a manual trial-and-error method was employed to determine the suitable concentration of $\mathrm{RO}^{-}$in each study and then other kinetic parameters were optimized. For each study, desorption rate coefficients $k_{\mathrm{d} i}$ of ferrihydrite or goethite remained constant under different conditions and the microbial reduction constant $k_{\text {red }}$ may vary depending on the reaction conditions. To calculate the total squared errors, the squared errors for both dissolved $\mathrm{As}(\mathrm{III})$ and $\mathrm{As}(\mathrm{V})$ were summed in each data set. In some cases, dissolved $\mathrm{As}(\mathrm{III})$ and $\mathrm{As}(\mathrm{V})$ concentrations were significantly different and we therefore put different weight factors for the squared errors of $\mathrm{As}(\mathrm{III})$ and $\mathrm{As}(\mathrm{V})$, based on the maximum $\mathrm{As}(\mathrm{III})$ and $\mathrm{As}(\mathrm{V})$ concentrations in the solution. Then both dissolved As(III) and As(V) concentration data can be properly fitted based on the total squared errors.

Note that, only one $k_{\mathrm{d}}$ value was fitted for each type of surface complexes since $k_{\mathrm{d} i}$ values were internally linked through equation 7 in the main text. For ferrihydrite, $k_{\mathrm{d} i}$ values varied among different experiments, reflecting the impact of variations of experimental conditions on $k_{\mathrm{d} i}$ values of ferrihydrite, which was discussed in the main text. For goethite, our modeling test showed variations of $k_{\mathrm{d} i}$ among different experiments were small. Therefore, we obtained $k_{\mathrm{d} i}$ values of goethite based on D3 and applied them to datasets D2 and D1. All $k_{\mathrm{d} i}$ values used for model calculations are presented in Table S5 and summarized in Figure S5. In ferrihydrite systems, $k_{\mathrm{d} 2, \mathrm{As}(\mathrm{V})}$ and $k_{\mathrm{d} 1, \mathrm{As}(\mathrm{III})}$ were fitted, and $k_{\mathrm{d} 1, \mathrm{As}(\mathrm{V})}$ and $k_{\mathrm{d} 3, \mathrm{As}(\mathrm{V})}$ were calculated according to equation 7 in the main text. In goethite systems, $k_{\mathrm{d} 2, \mathrm{As}(\mathrm{V}) \text {, }}$ $k_{\mathrm{d} 3, \mathrm{As}(\mathrm{V}),} k_{\mathrm{d} 1, \mathrm{As}(\mathrm{III})}$ and $k_{\mathrm{d} 2, \mathrm{As}(\mathrm{III})}$ were fitted, and $k_{\mathrm{d} 1, \mathrm{As}(\mathrm{V})}$ were calculated according to equation 7 in the main text. In D2, D4 and D9, model performance was not sensitive to $k_{\mathrm{d} i}$ values of As(III) and we simply set $k_{\mathrm{d} i}$ values of As(III) to equal to that of $\mathrm{As}(\mathrm{V})$. 
Table S5. Desorption rate coefficients of ferrihydrite and goethite binding sites

\begin{tabular}{|c|c|c|c|c|c|c|}
\hline Iron oxide & Data set & $k_{\mathrm{d} 1, \mathrm{As}(\mathrm{V})}\left(\mathrm{h}^{-1}\right)$ & $k_{\mathrm{d} 2, \mathrm{As}(\mathrm{V})}\left(\mathrm{h}^{-1}\right)$ & $k_{\mathrm{d} 3, \mathrm{As}(\mathrm{V})}\left(\mathrm{h}^{-1}\right)$ & \multicolumn{2}{|c|}{$k_{\mathrm{d} 1, \mathrm{As}(\mathrm{III})}\left(\mathrm{h}^{-1}\right)$} \\
\hline & D1 & $1.6 \times 10^{-5}$ & $3.5 \times 10^{-3}$ & $6.0 \times 10^{-4}$ & \multicolumn{2}{|c|}{1} \\
\hline & D2 & $1.6 \times 10^{-5}$ & $3.3 \times 10^{-3}$ & $5.8 \times 10^{-4}$ & \multicolumn{2}{|c|}{$3.3 \times 10^{-3}$} \\
\hline & 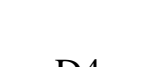 & $8.1 \times 10^{-6}$ & $1.7 \times 10^{-3}$ & $3.0 \times 10^{-4}$ & \multicolumn{2}{|c|}{$1.7 \times 10^{-3}$} \\
\hline & 14 & $1.9 \times 10^{-5}$ & $4.0 \times 10^{-3}$ & $7.0 \times 10^{-4}$ & \multicolumn{2}{|c|}{$4.0 \times 10^{-3}$} \\
\hline & D5 & $1.7 \times 10^{-5}$ & $9.1 \times 10^{-3}$ & $6.2 \times 10^{-4}$ & \multicolumn{2}{|c|}{$1.3 \times 10^{-3}$} \\
\hline $\mathrm{Fh}$ & D6 & $3.4 \times 10^{-6}$ & $7.0 \times 10^{-4}$ & $1.2 \times 10^{-4}$ & \multicolumn{2}{|c|}{$2.8 \times 10^{-3}$} \\
\hline & D7 & $2.9 \times 10^{-6}$ & $6.0 \times 10^{-4}$ & $1.0 \times 10^{-4}$ & \multicolumn{2}{|c|}{$7.0 \times 10^{-4}$} \\
\hline & D8 & $7.6 \times 10^{-6}$ & $1.6 \times 10^{-3}$ & $2.8 \times 10^{-4}$ & \multicolumn{2}{|c|}{$3.5 \times 10^{-3}$} \\
\hline & D9 & $3.4 \times 10^{-6}$ & $7.0 \times 10^{-3}$ & $1.2 \times 10^{-4}$ & \multicolumn{2}{|c|}{$7.0 \times 10^{-3}$} \\
\hline & $\mathrm{D} 10$ & $2.8 \times 10^{-6}$ & $6.0 \times 10^{-4}$ & $1.0 \times 10^{-4}$ & \multicolumn{2}{|c|}{$2.0 \times 10^{-3}$} \\
\hline & D11 & $3.4 \times 10^{-6}$ & $7.0 \times 10^{-3}$ & $1.0 \times 10^{-3}$ & \multicolumn{2}{|c|}{$1.4 \times 10^{-3}$} \\
\hline Iron oxide & Data set & $k_{\mathrm{d} 1, \mathrm{As}(\mathrm{V})}\left(\mathrm{h}^{-1}\right)$ & $k_{\mathrm{d} 2, \mathrm{As}(\mathrm{V})}\left(\mathrm{h}^{-1}\right)$ & $k_{\mathrm{d} 3, \mathrm{As}(\mathrm{V})}\left(\mathrm{h}^{-1}\right)$ & $\begin{array}{c}k_{\mathrm{d} 1, \mathrm{As}(\mathrm{III})} \\
\left(\mathrm{h}^{-1}\right) \\
\end{array}$ & $\begin{array}{c}k_{\mathrm{d} 2, \mathrm{As}(\mathrm{III})} \\
\left(\mathrm{h}^{-1}\right)\end{array}$ \\
\hline \multirow{3}{*}{ Gt } & D1 & $2.5 \times 10^{-6}$ & $8.0 \times 10^{-3}$ & $1.7 \times 10^{-1}$ & I & 1 \\
\hline & $\mathrm{D} 2$ & $2.5 \times 10^{-6}$ & $8.0 \times 10^{-3}$ & $1.7 \times 10^{-1}$ & $1.1 \times 10^{-2}$ & $9.9 \times 10^{-2}$ \\
\hline & D3 & $2.5 \times 10^{-6}$ & $8.0 \times 10^{-3}$ & $1.7 \times 10^{-1}$ & $1.1 \times 10^{-2}$ & $9.9 \times 10^{-2}$ \\
\hline
\end{tabular}

Fh: $k_{\mathrm{d} 1, \mathrm{As}(\mathrm{V})}$ : protonated bidentate sites for $\mathrm{As}(\mathrm{V}) ; k_{\mathrm{d} 2, \mathrm{As}(\mathrm{V})}$ : non-protonated bidentate sites for

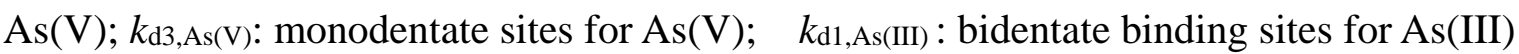
Gt: $k_{\mathrm{d} 1, \mathrm{As}(\mathrm{V})}$ : protonated bidentate sites for $\mathrm{As}(\mathrm{V}) ; k_{\mathrm{d} 2, \mathrm{As}(\mathrm{V})}$ : non-protonated bidentate sites for $\mathrm{As}(\mathrm{V}) ; k_{\mathrm{d} 3, \mathrm{As}(\mathrm{V})}$ : monodentate sites for $\mathrm{As}(\mathrm{V}) ; k_{\mathrm{d} 1, \mathrm{As}(\mathrm{III})}$ : bidentate binding sites for As(III);

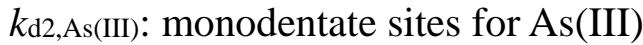

\section{Sensitivity and uncertainty tests}

We conducted model sensitivity tests on model fitting parameters. We varied each model parameter while keeping other parameters constant, and then calculated correspondent total squared errors (TSEs). Representative results are presented in Figure S6 for goethite systems and Figures S7 and S8 for ferrihydrite systems. Overall, model performance had different sensitivities to different model parameters. In all systems, variations of $k_{0}$ and $b$ can significantly affect model performance since these two parameters directly controlled As(V) reduction reactions. In comparison, model calculations had varying sensitivity to the desorption rate coefficients $k_{\mathrm{d} i}$. In some cases, the $k_{\mathrm{d} i}$ values of $\mathrm{As}(\mathrm{V})$ had significant impact on the model performance while $k_{\mathrm{d} i}$ values of As(III) had little impact for those studies 
analyzed (Figures S6 and S7). In some cases (e.g., D5), As(III) adsorption on iron oxides were significant and model calculations were also sensitive to $k_{\mathrm{d} i}$ values of $\mathrm{As}(\mathrm{III})$ (Figure S8).

We further assessed the uncertainties of model fitting parameters. The standard deviations of model fitting parameters were calculated using the SolverAid macro in Excel. ${ }^{18}$ Note that we only had the average values at each reaction time from the literature data and there were no raw data of the replicates. Therefore, the uncertainty analysis only reflected the parameter uncertainties due to the model. For some representative studies, we presented model simulations using the model fitting parameters and those minus and plus one standard deviation (Figures S9-S11). Overall model uncertainties varied among different studies. For those studies with most experimental data (e.g., D1, D2, D3, D4, and D8), the standard deviations of most model parameters were small and model performed reasonably well within the ranges of parameters simulated (Figure S9). The largest uncertainties of model parameters were from data sets with small numbers of data points (e.g., $k_{0}$ and $b$ in D5 and D9), which was not able well constrain the model fitting parameters involving multiple reaction processes (Figure S11).

Overall, our sensitivity and uncertainty tests indicated that the lack of experimental data that can constrain the model parameters in different studies resulted in different uncertainties of model fitting parameters and errors associated with model calculations. The coupled kinetics model had a number of fitting parameters to be determined, which represented different kinetic processes. If one of the processes was not well constrained by the kinetic data, the correspondent kinetic parameters cannot be reliably determined, resulting large standard deviations. Further studies with carefully designed experiments and large data sets will help to calibrate the model parameters and improve the accuracy of model calculations. 

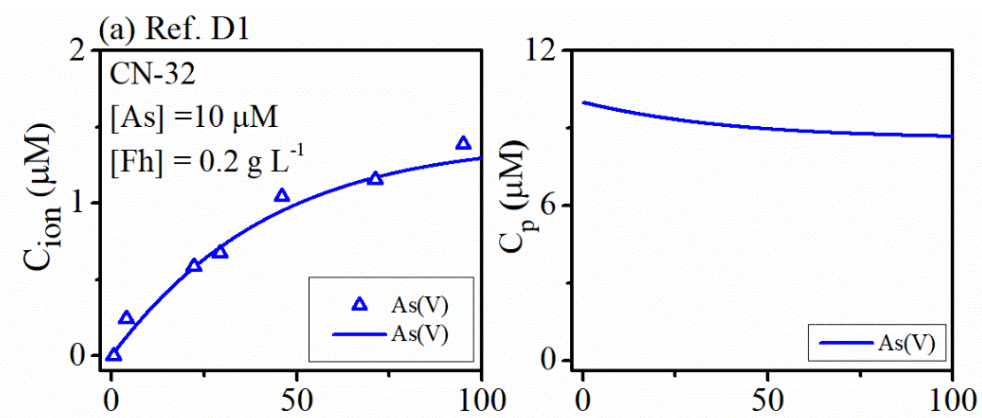

(b) Ref. D1
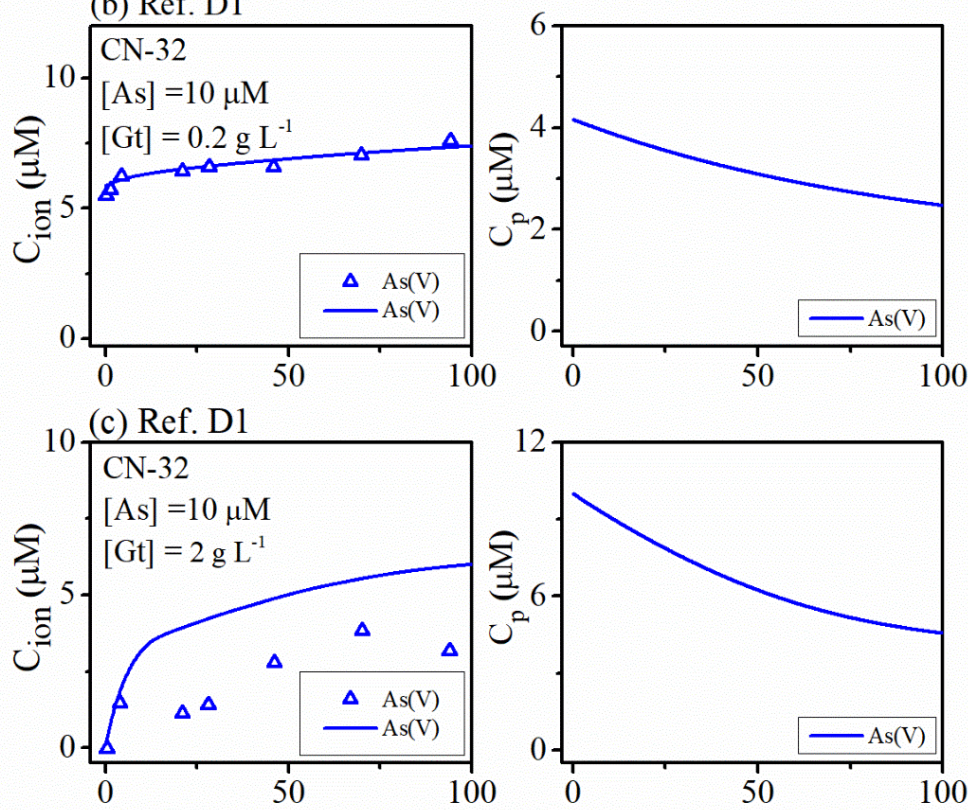

time $(\mathrm{h})$

Figure S1. Kinetics of As(V) desorption from (a) ferrihydrite and (b) and (c) goethite upon addition of the deactivated $\mathrm{CN}-32$ bacteria $(\mathrm{RMSE}=0.077,0.23,2.49 \mu \mathrm{M})$. For each plot, the left panel showed the kinetic data and model fits of the solution As(V) concentrations, and the right panel showed model calculations of the adsorbed $\mathrm{As}(\mathrm{V})$ concentrations on iron oxides with reaction time. Key experimental conditions are presented in the legends. Symbols represent the experimental data and lines are model calculations. Data were from data set D1. 

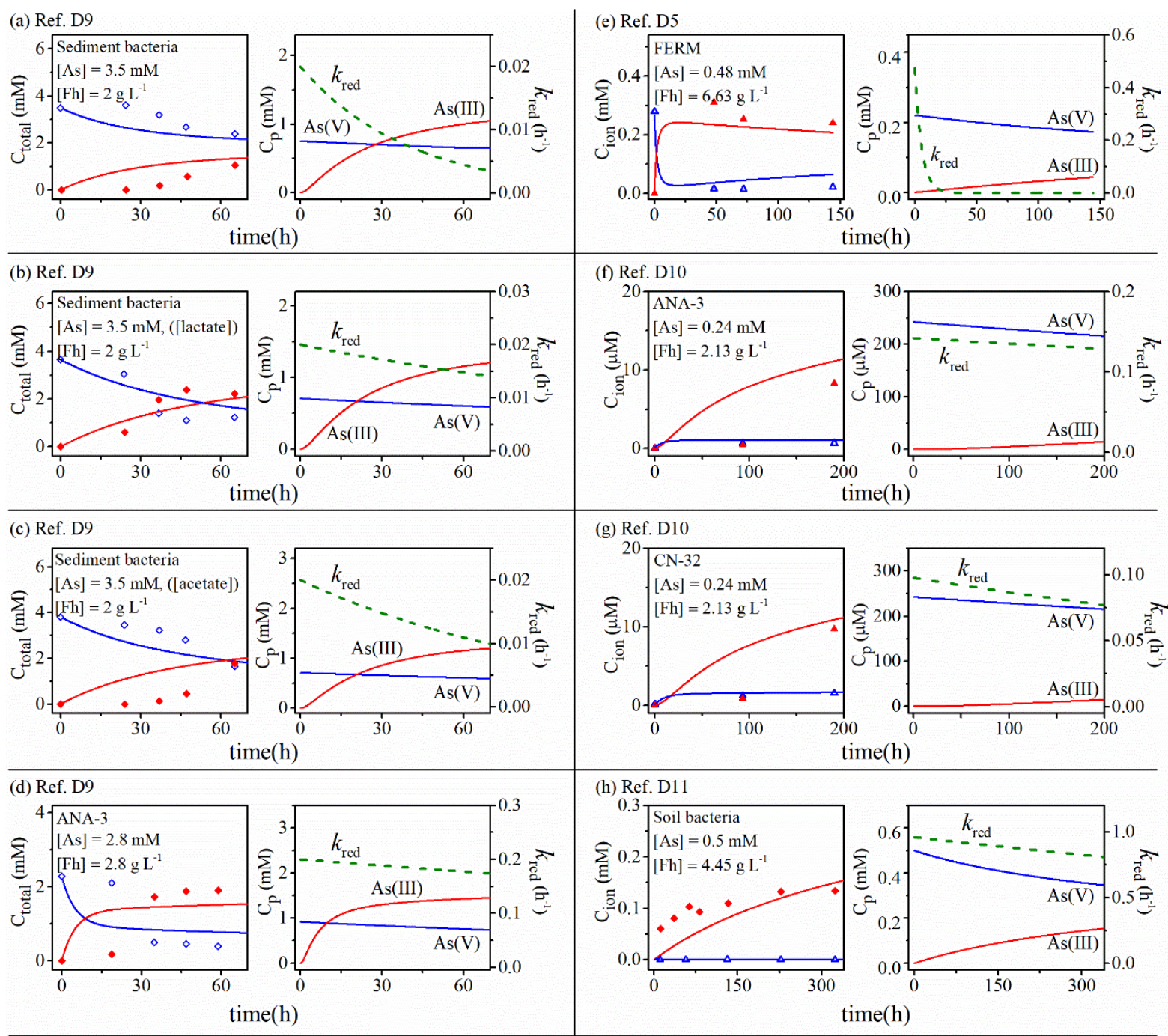

211 Figure S2. Kinetics of As(V) reduction by bacteria and $\mathrm{As}(\mathrm{III}) / \mathrm{As}(\mathrm{V})$ adsorption/desorption 212 on ferrihydrite $(\mathrm{RMSE}=0.50,0.20,0.66,0.44,0.039,0.0034,0.0030$, and $0.032 \mathrm{mM}$ from 213 panel a to panel h). For each plot, the left panel showed the kinetic data and model fits of the 214 solution As(III) and As(V) concentrations, and the right panel showed model calculations of 215 the adsorbed $\mathrm{As}(\mathrm{III})$ and $\mathrm{As}(\mathrm{V})$ concentrations on iron oxides and the changes of microbial reduction rate coefficients $k_{\text {red }}$ with reaction time. Key experimental conditions are presented in the legends. Symbols represent the experimental data and lines are model calculations. 

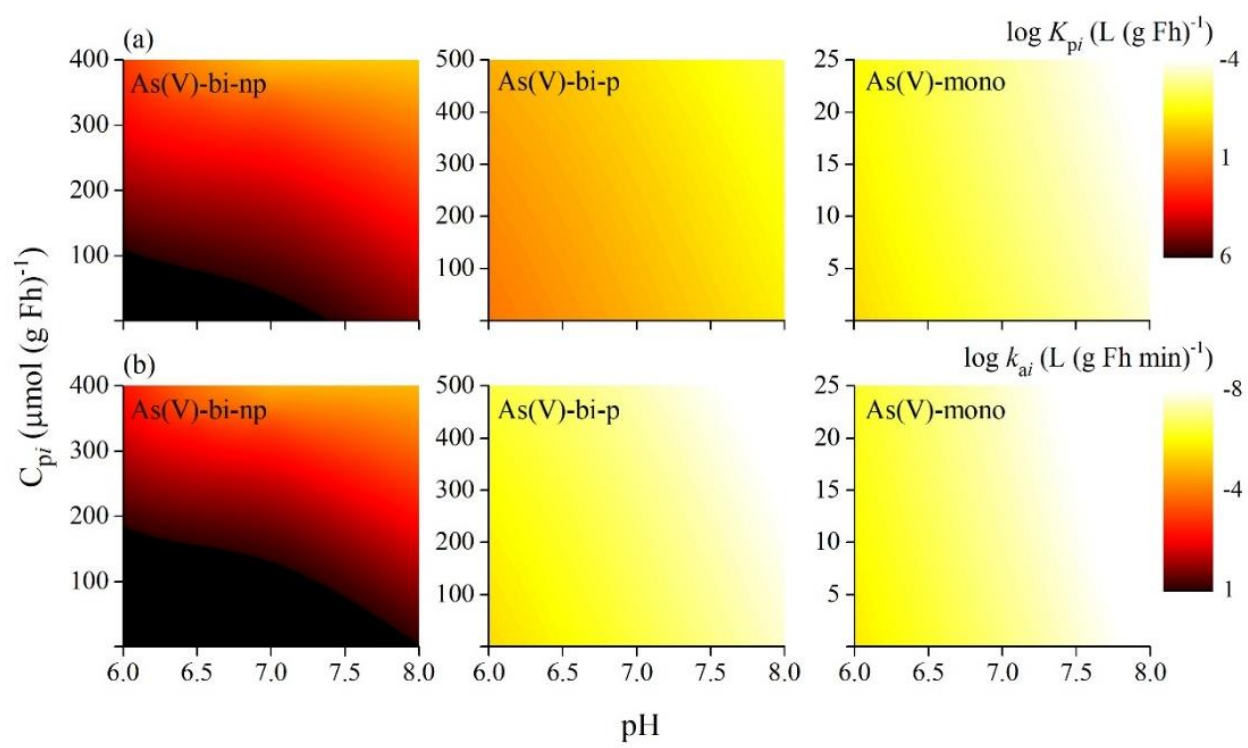

Figure S3. Variations of (a) equilibrium partition coefficients $K_{\mathrm{p} i}$ and (b) adsorption rate coefficients $k_{\mathrm{a} i}$ of $\mathrm{As}(\mathrm{V})$ of various ferrihydrite binding sites as a function of reaction $\mathrm{pH}$ and adsorbed As $(\mathrm{V})$ concentrations. Refer to the text for the definition of each binding site. The conditions used for calculations were from data set D2.
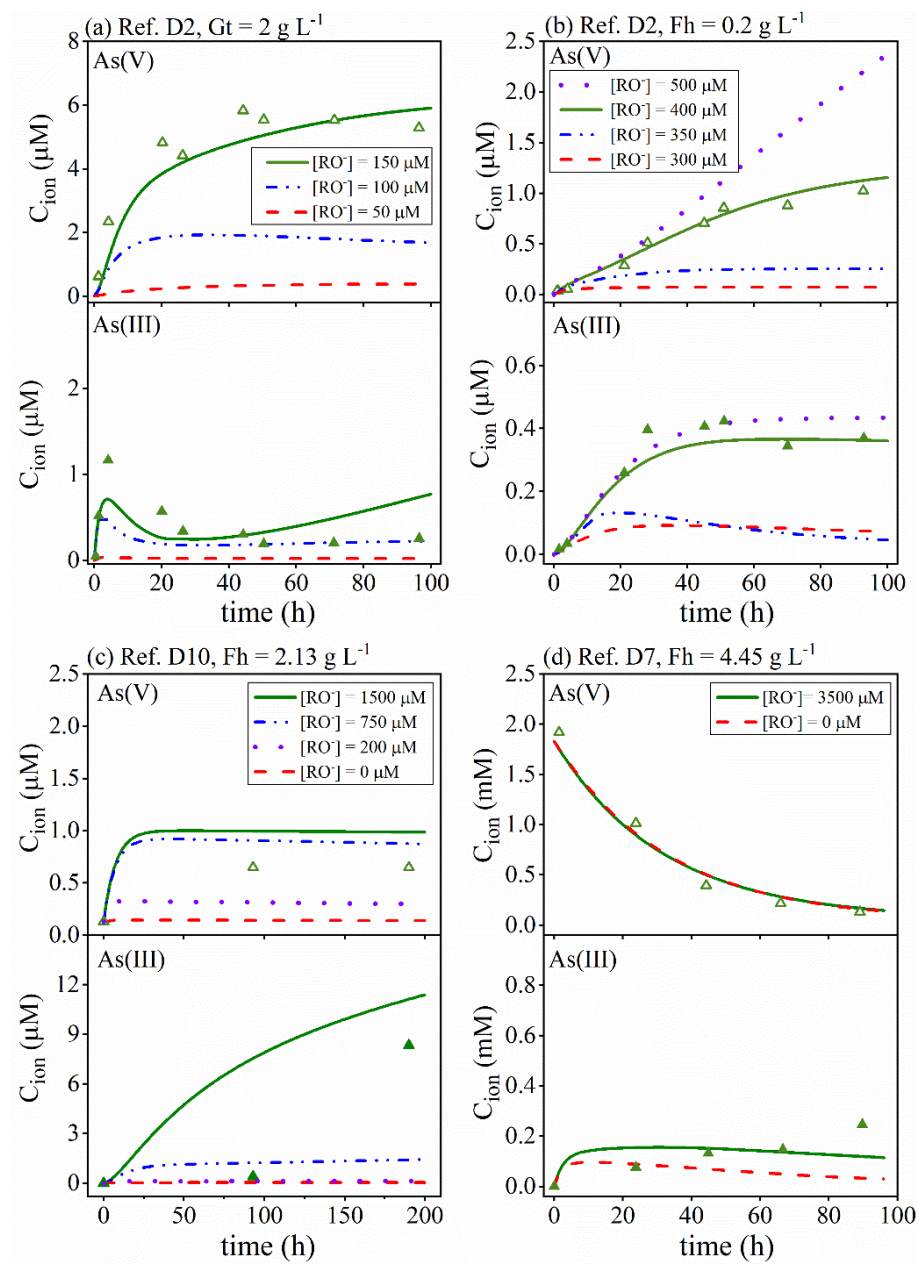

Figure S4. The sensitivity test of the $\mathrm{RO}^{-}$concentrations in the kinetics model. The correspondent data sets are shown in the figures. 


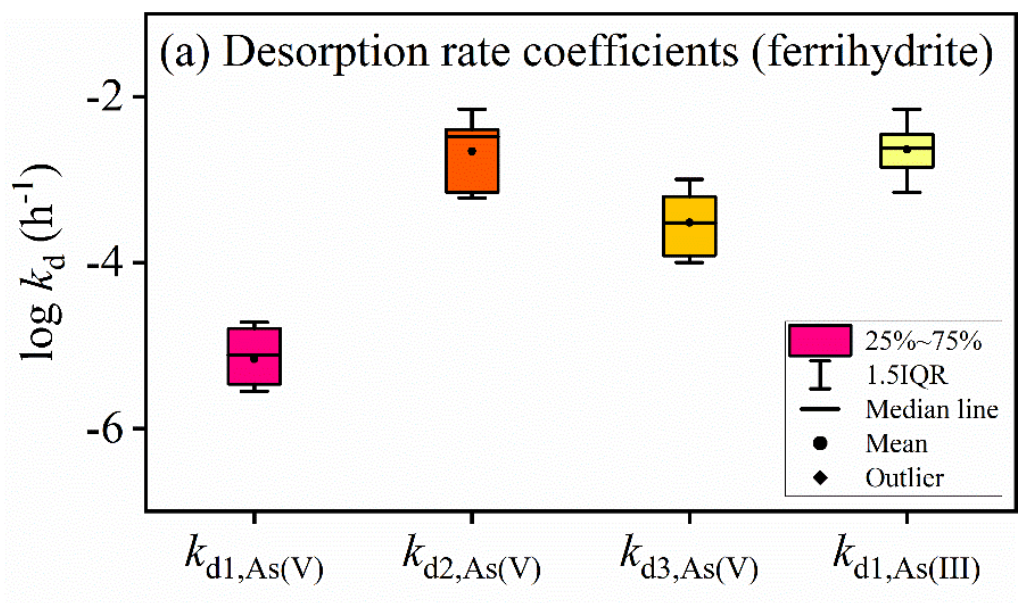

227 Figure S5. (a) box-plot for desorption rate coefficients of different binding sites of ferrihydrite 228 for $\mathrm{As}(\mathrm{V})$ and $\mathrm{As}(\mathrm{III})(\mathrm{n}=12), k_{\mathrm{d} 1, \mathrm{As}(\mathrm{V})}-k_{\mathrm{d} 3, \mathrm{As}(\mathrm{V})}$ : desorption rate coefficients of $\mathrm{As}(\mathrm{V})$ binding 229 sites, $k_{\mathrm{d} 1}$ for protonated bidentate sites, $k_{\mathrm{d} 2}$ for nonprotonated bidentate sites, and $k_{\mathrm{d} 3}$ for 230 monodentate sites; $k_{\mathrm{d} 1, \mathrm{As}(\mathrm{III})}$ : As(III) bidentate binding sites; (b) desorption rate coefficients of

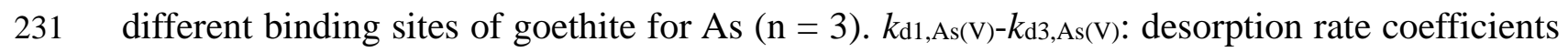
232 of $\mathrm{As}(\mathrm{V})$ binding sites, $k_{\mathrm{d} 1}$ for protonated bidentate sites, $k_{\mathrm{d} 2}$ for nonprotonated bidentate sites,

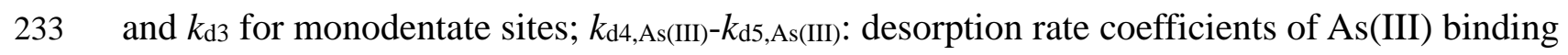
234 sites, $k_{\mathrm{d} 4}$ for bidentate sites and $k_{\mathrm{d} 5}$ for monodentate site. $25 \%-75 \%$ : the first quartile and the 235 third quartile; 1.5IQR: the top line and bottom line represent the maximum and the minimum 236 value; Median line: the median of all data; Mean: the average value of all data; Outlier: the data point numerically distant from the rest of the data. 

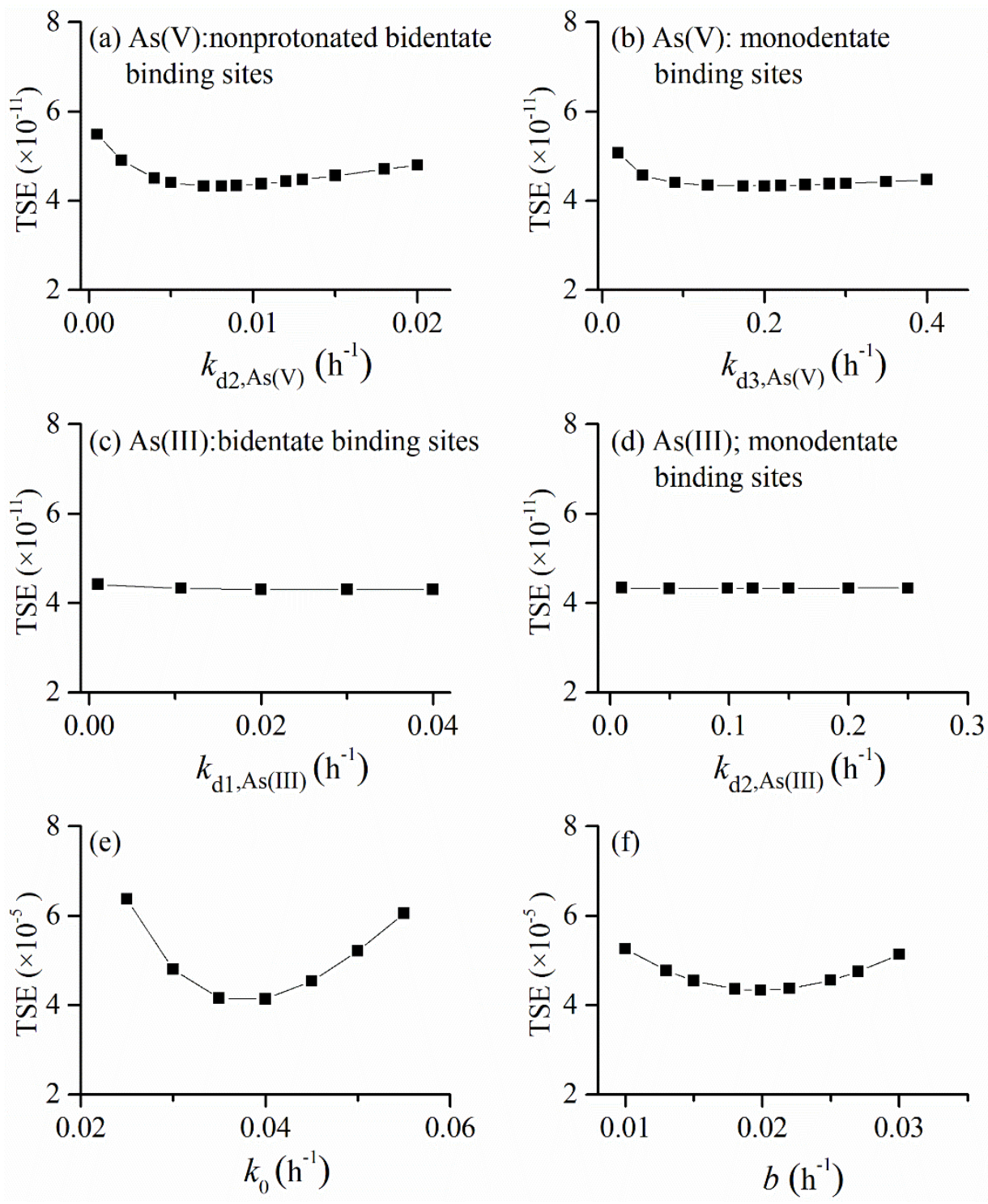

239 Figure S6. Sensitivity tests for different model fitting parameters based the modeling results 240 of goethite systems in D3 dataset (no phosphate). Please refer to the text for specific reaction 241 conditions. 

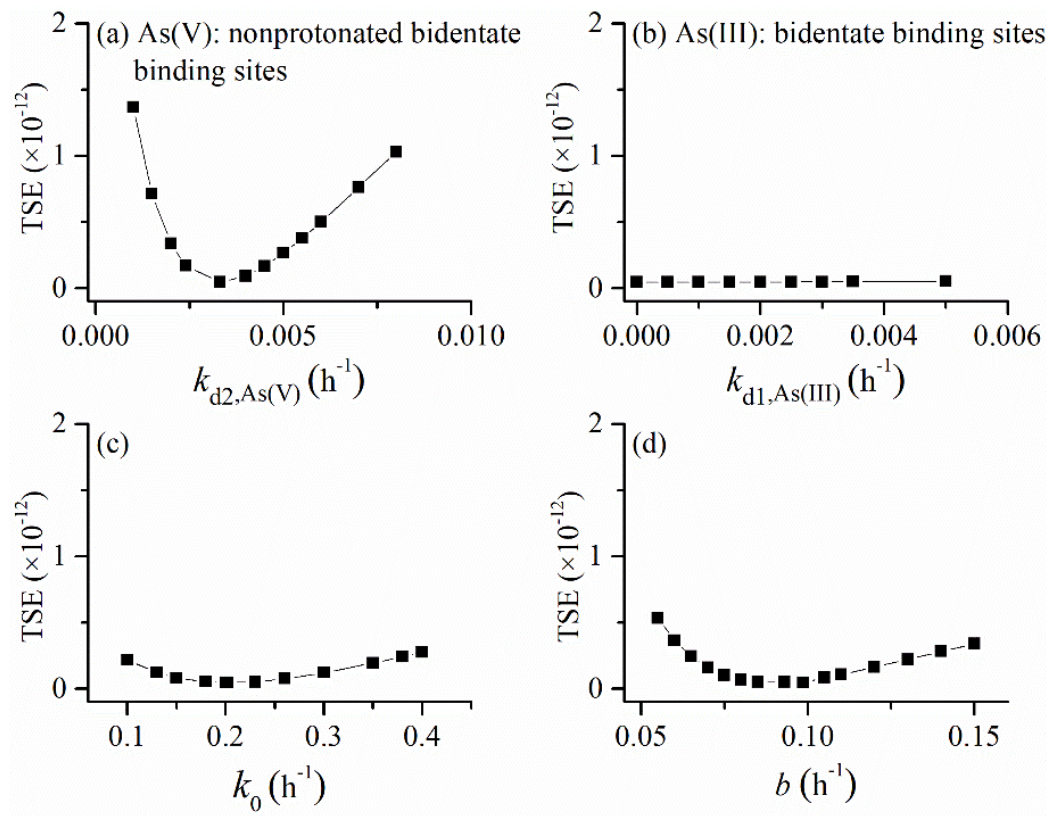

243 Figure S7. Sensitivity tests for different model fitting parameters based the modeling results of ferrihydrite systems in D2 dataset. Please refer to the text for specific reaction conditions.
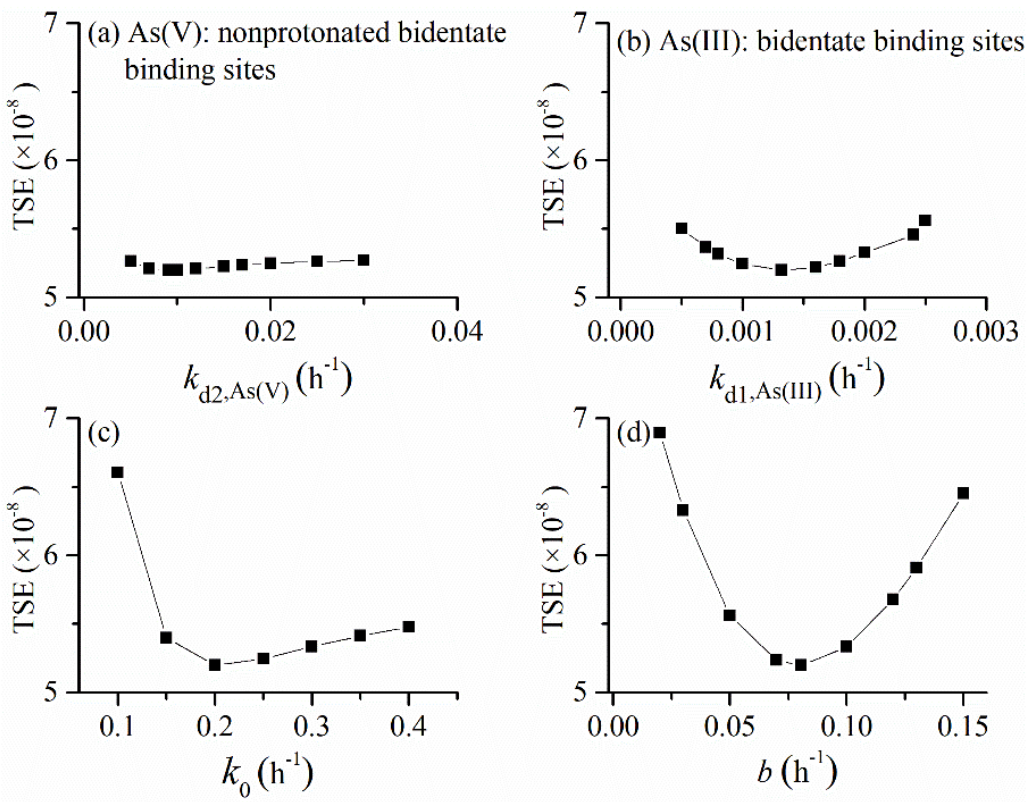

247 Figure S8. Sensitivity tests for different model fitting parameters based the modeling results 248 of ferrihydrite systems in D5 dataset (bacteria: ANA-3). Please refer to the text for specific 249 reaction conditions. 

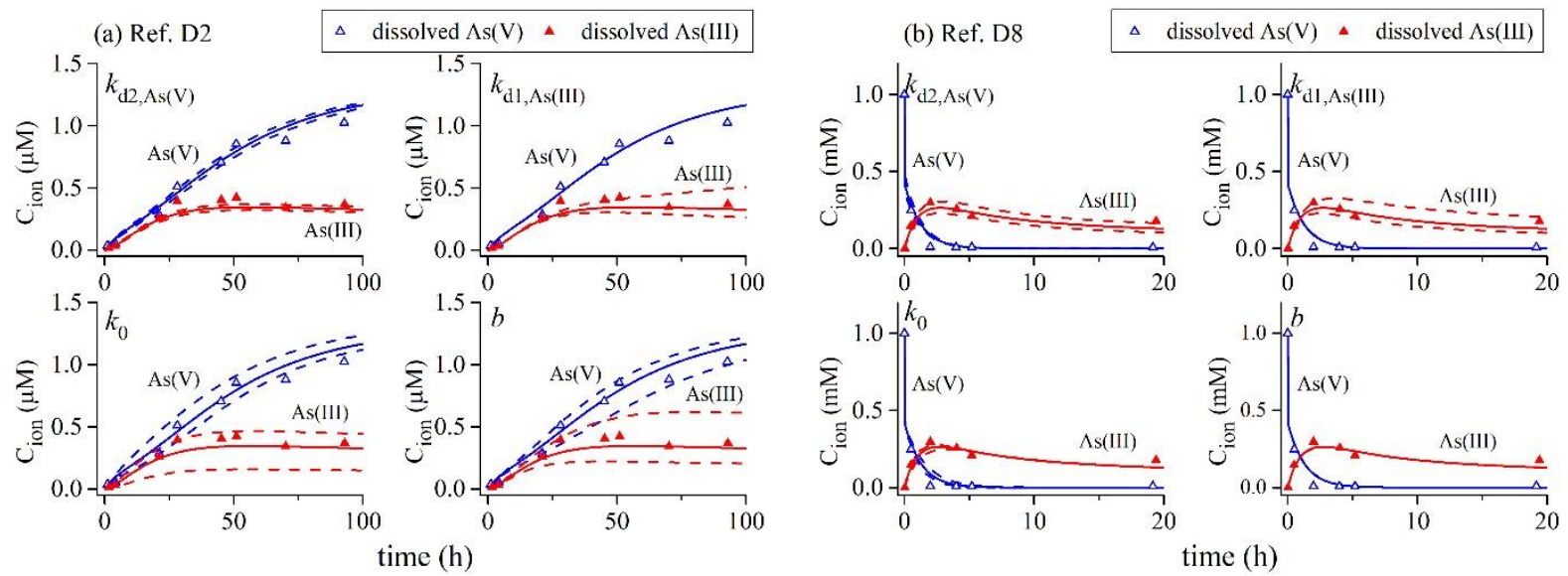

Figure S9. Uncertainty tests for different model fitting parameters based the modeling results of ferrihydrite systems in D2 and D8 dataset. Please refer to the text for specific reaction conditions. Symbols are experimental data. Solid lines are model calculations with the model fitting parameter and dashed lines are model calculations with the model fitting parameter plus and minus one standard deviation.
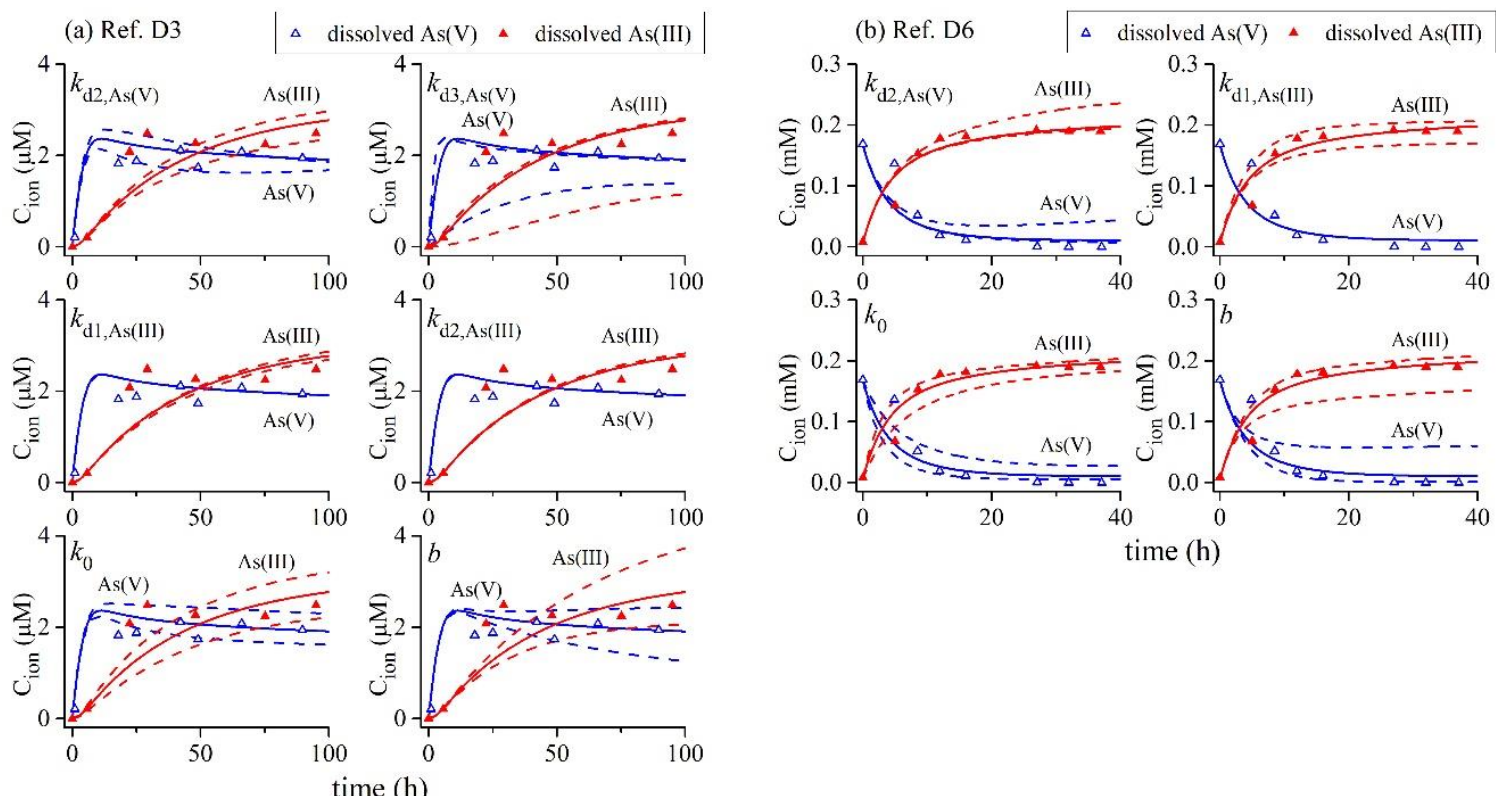

Figure S10. Uncertainty tests for different model fitting parameters based the modeling results of goethite systems in D3 dataset ([phosphate] = 0) and D6 dataset. Please refer to the text for specific reaction conditions. Symbols are experimental data. Solid lines are model calculations with the model fitting parameter and dashed lines are model calculations with the model fitting parameter plus and minus one standard deviation. 


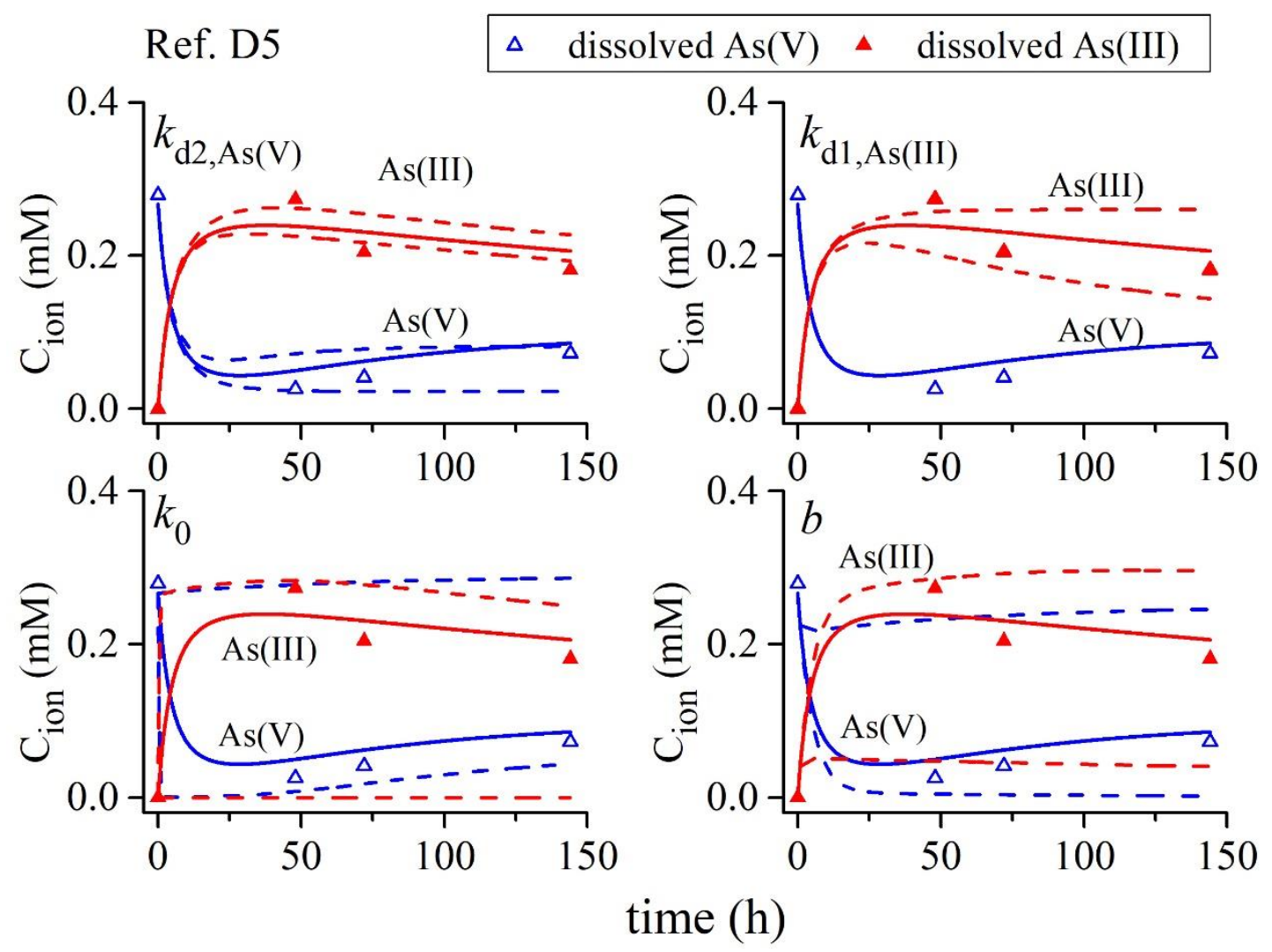

Figure S11. Uncertainty tests for different model fitting parameters based the modeling results of ferrihydrite systems in D5 dataset (bacteria: ANA-3). Please refer to the text for specific reaction conditions. Symbols are experimental data. Solid lines are model calculations with the model fitting parameter and dashed lines are model calculations with the model fitting parameter plus and minus one standard deviation.

\section{Reference for the supporting information}

1. Huang, J.-H., Characterising microbial reduction of arsenate sorbed to ferrihydrite and its concurrence with iron reduction. Chemosphere 2018, 194, 49-56.

2. Huang, J. H., Impact of competitive adsorption on microbial arsenate reduction at the water-goethite interface. Appl. Geochem. 2018, 88, 59-67. 3. Huang, J. H.; Elzinga, E. J.; Brechbuehl, Y.; Voegelin, A.; Kretzschmar, R., Impacts of Shewanella putrefaciens strain $\mathrm{CN}-32$ cells and extracellular polymeric substances on the sorption of As(V) and As(III) on Fe(III)-(hydr)oxides. Environ. Sci. Technol. 2011, 45, (7), 2804-10. Influence of arsenate adsorption to ferrihydrite, goethite, and boehmite on the kinetics of arsenate reduction by Shewanella putrefaciens strain CN-32. Environ. Sci. Technol. 2011, 45, 282 (18), 7701.

283 5. Langner, H. W.; Inskeep, W. P., Microbial reduction of arsenate in the presence of ferrihydrite. Environ. Sci. Technol. 2000, 34, (15), 3131-3136.

285 6. Dzombak, D. A., and F.M.M. Morel., Surface complexation modelling: Hydrous ferric oxide,. Wiley-Interscience: New York., 1990. 

natural organic matter: roles of the carboxylic and phenolic Sites. Environ. Sci. Technol. 289 2016, 50, (19), 10476-10484.

290 8. Tian, L.; Shi, Z.; Lu, Y.; Dohnalkova, A.; Lin, Z.; Dang, Z., Kinetics of cation and 291 oxyanion adsorption and desorption on ferrihydrite: roles of ferrihydrite binding sites and a 292 unified model. Environ. Sci. Technol. 2017, 51, 10605-10614.

293 9. Peng, L.; Liu, P.; Feng, X.; Wang, Z.; Cheng, T.; Liang, Y.; Lin, Z.; Shi, Z., Kinetics of 294 heavy metal adsorption and desorption in soil: Developing a unified model based on chemical 295 speciation. Geochim. Cosmochim. Acta 2018, 224, 282-300.

296 10. Tian, H.; Shi, Q.; Jing, C., Arsenic biotransformation in solid waste residue: comparison 297 of contributions from bacteria with arsenate and iron reducing pathways. Environ. Sci.

298 Technol. 2015, 49, (4), 2140-6.

299 11. Peng, S.; Wang, P.; Peng, L.; Cheng, T.; Sun, W.; Shi, Z., Predicting heavy metal partition 300 equilibrium in soils: roles of soil components and binding sites. Soil Science Society of $301 \quad$ America Journal 2018.

302 12. Tiberg, C.; Gustafsson, J. P., Phosphate effects on cadmium(II) sorption to ferrihydrite. J. 303 Colloid Interface Sci. 2016, 471, 103-111.

304 13. Tiberg, C.; Sjöstedt, C.; Persson, I.; Gustafsson, J. P., Phosphate effects on copper(II) and 305 lead(II) sorption to ferrihydrite. Geochim. Cosmochim. Acta 2013, 120, 140-157.

306 14. Gustafsson, J. P.; Bhattacharya, P., Geochemical modelling of arsenic adsorption to oxide 307 surfaces. 2007, 9, 159-206.

308 15. Gustafsson, J. P., Arsenate adsorption to soils: Modelling the competition from humic 309 substances. Geoderma 2006, 136, (1-2), 320-330.

310 16. Weng, L. P.; Temminghoff, E. J. M.; van Riemsdijk, W. H., Contribution of individual 311 sorhents to the control of heavy metal activity in sandy soil. Environ. Sci. Technol. 2001, 35, 312 (22), 4436-4443.

313 17. Deng, Y.; Li, Y.; Li, X.; Sun, Y.; Ma, J.; Lei, M.; Weng, L., Influence of calcium and 314 phosphate on $\mathrm{pH}$ dependency of arsenite and arsenate adsorption to goethite. Chemosphere 315 2018, 199, 617-624.

316 18. de Levie, R., How to use Excel in analytical chemistry and in general scientific data 317 analysis. Cambridge University Press: Cambridge, UK, 2004; p 487. 